\title{
Remorse, Apology, and Mercy
}

\author{
Jeffrie G. Murphy*
}

It is commonly believed that legal mercy for those guilty of serious crimes is most appropriately bestowed upon those criminals who exhibit sincere remorse and repentance over what they have done-a remorse and repentance often represented by apologies to victims, survivors, and the community as a whole. As the public interest in the Karla Faye Tucker case demonstrated, many people find these displays of remorse particularly compelling if they are presented as a consequence of religious conversion. In contrast, the word "remorseless" is often used to describe those criminals who are viewed as the worst of the worst and thus as least deserving of legal mercy.

This essay-a modification of some of the author's earlier work-explores the nature of remorse, its relation to religion, the role it plays in the assessment of moral character, and the role that such a character assessment might play in decisions to grant legal mercy-in particular, decisions of judges at the time of sentencing or decisions of executives with the power to grant clemency. The complex relationship that acts of apology bear to the kind of remorse that, at least in the minds of many, makes a criminal a legitimate candidate for legal mercy is also examined. The author, exploring both moral and epistemic issues, will express considerable skepticism toward relying on judgments about offender remorse at the time of sentencing, but less skepticism about relying on such judgments at the time of an executive decision to grant clemency.

[One] night later merciless Grendel

struck again with more gruesome murders.

Malignant by nature, he never showed remorse.

Beowulf

Seamus Heaney translation

* Regents' Professor of Law, Philosophy, and Religious Studies at Arizona State University. I thank Stephanos Bibas, Richard Dagger, Antony Duff, Stephen Garvey, Alan Michaels, Herbert Morris, Mary Sigler, Eleonore Stump, Margaret Walker, James Weinstein, and students in my current jurisprudence seminar for their comments on an earlier draft of this essay. I am particularly grateful to my colleague Michael White, whose comments forced me to think more carefully about my use of $J$. $L$. Austin's theory of speech acts, and to my wife Ellen Canacakos for the insights she has provided from her practice as a psychotherapist. 
On this third planet from the sun, among the signs of bestiality

A clear conscience is Number One.

"In Praise of Feeling Bad About Yourself"

Wislawa Szymborska

\section{INTRODUCTION}

It is commonly even if not universally believed that the very worst of evildoers are those who are utterly without remorse for the evil that they have done-an absence often understandably inferred from their unwillingness to express remorse by apologizing or begging forgiveness or by their not engaging in appropriate non-verbal expressive behavior - seeking out punishment, for example. Such absence of remorse may, in the words of Wislawa Szymborska, be a "sign of bestiality" or, in the phrase of Seamus Heaney, reveal them as "malignant by nature." In the legal world, such judgments can be found at various points in the criminal process-where absence of remorse may be cited as an aggravating factor that legitimately should incline us to greater harshness and certainly not to greater compassion or mercy. Here are a few examples-one from a clemency decision, one from a prosecuting attorney's argument at the sentencing stage of a criminal trial, one from a trial judge justifying a sentence, one from a distinguished legal scholar, and one from a United States Supreme Court decision:

Is Williams' [claimed] redemption complete and sincere, or is it just a hollow promise? Stanley Williams insists [against overwhelming evidence to the contrary] that he is innocent, and that he will not and should not apologize or otherwise atone for the murders of the four victims in this case. Without an apology and atonement for these senseless and brutal killings there can be no redemption. In this case, the one thing that would be the clearest indication of complete remorse and full redemption is the one thing Williams will not do. ${ }^{1}$

Have you observed any repentance by Mr. McCleskey? Has he exhibited to you any sorrow? Have you seen any tears in his eyes for this act that he has done? ${ }^{2}$

1 Statement of Decision, Request for Clemency by Stanley Williams (Dec. 12, 2005) (corrected version), available at http://www.governor.ca.gov/govsite/pdf/press_release_2005/Williams_Clemency_ Decision.pdf, signed by California Governor Amold Schwarzenegger. Governor Schwarzenegger denied Crips founder Stanley "Tookie" Williams executive clemency for his death sentence.

2 These rhetorical questions were raised in 1978 by Atlanta District Attorney Richard Parker as he argued before the jury that Warren G. McCleskey, convicted of murdering a police officer, should be shown no mercy but should be sentenced to death. (He was sentenced to death.) The quoted passage is from the transcript of the 1978 trial. 
The vicious acts you committed on December 7,1993, were the acts of a coward. What could be more cowardly than entering a train filled with unsuspecting, homebound commuters and systematically shooting them at point-blank range? ... What is even more remarkable is your total lack of remorse. $^{3}$

It is true that all of us are guilty of some immoralities, probably on a daily basis. Yet for most [of us] . . the immoralities in question are things like manipulating others unfairly; not caring deeply enough about another's suffering; not being charitable for the limitations of others; convenient lies; and so forth .... Few of us have raped and murdered a woman, drowned her three small children, and felt no remorse about it. ${ }^{4}$

[S]erious prejudice could result if medication inhibits the defendant's capacity ... to demonstrate remorse or compassion ... . In [capital cases] assessments of character and remorse may carry great weight and, perhaps, be determinative of whether the offender lives or dies. ${ }^{5}$

Not everyone, it should be noted, agrees with the common view that the remorseless wrongdoer is worse in the sense of deserving more punishment than the wrongdoer who feels remorse or with the related view that the remorseful wrongdoer should to some degree gain our sympathy as a ground for mercy. After all, if remorseless wrongdoers really are "bestial" or "malignant by nature," they may be seen as standing outside the moral domain in which such concepts as desert or guilt or punishment make clear sense. These creatures seem to be, if not-in fairness to beasts-literally beasts, then, as psychopaths or sociopaths, possessing a trait that Kant called "moral death"- an absence of moral feeling so pervasive as to render them not fully human from the moral point of view. Perhaps, like mad dogs, they are- at least in principle--more candidates for extermination than for punishment. ${ }^{6}$

3 Judge Donald E. Belfi, Remarks at the Sentencing of Colin Ferguson (Mar. 22, 1995). These remarks were offered by Nassau County Court Judge Donald E. Belfi as he defended the sentence of two hundred years that he imposed on Colin Ferguson, a man convicted on six counts of murder and nineteen counts of attempted murder in an attack on commuters on a Long Island Railroad train.

4 Professor Michael S. Moore here uses the example of remorseless killer Steven Judy as grounds for rejecting Jesus' famous "He that is without $\sin$... let him first cast a stone" remark as an objection to retribution and characterizing such a use as "pretty clumsy moral philosophy." Michael S. Moore, The Moral Worth of Retribution, in RESPONSIBILITY, CHARACTER AND THE EMOTIONS 188 (Ferdinand Schoeman ed., 1987).

5 Riggins v. Nevada, 504 U.S. 127, 143-44 (1992) (Kennedy, J., concurring). Realizing that sentencing agents will naturally think that a criminal lacking in remorse is particularly deserving of the death penalty, Justice Kennedy wants to make sure that an offender's failure to express remorse is truly a function of his actual character and not medication.

6 For an exploration of the Kantian concept of "moral death" and its implications for responsibility, see Jeffrie G. Murphy, Moral Death: A Kantian Essay on Psychopathy, 82 ETHICs 284 
The writer Cynthia Ozick, for example, was asked by Simon Wiesenthal to consider if the claimed remorseful repentance and plea for forgiveness from Karl, a young dying Nazi SS soldier who had participated in the cruel murder of a great many Jews, should be a ground for forgiving the young soldier or at least thinking better of him. Even on the assumption that the claimed remorse was sincere, Ozick did not consider it a valid ground for softening our judgment of the soldier. Indeed, she thought his repentance was an aggravating factor rather than a mitigating one, a factor that made him worse than an unrepentant murderer. The unrepentant murderer, she speculated, is likely to be simply a thoughtless and ignorant thug or perhaps a sociopath-malignant by bestial nature rather than by choice and thus not fully responsible. The remorseful murderer, however, reveals in his very remorse that he had at the time of his act a moral conscience and knew that he was doing evil. Thus, in order to do the evil, he had to suppress that moral conscience; and this, in Ozick's judgment, makes him worse than the mere thug and thus worthy of the most severe punishment. Should we then forgive or show mercy to him on the basis of his remorse? Certainly not, says Ozick, and on the contrary says this of the dying SS soldier:

We condemn the intelligent man of conscience because ... though at heart not a savage, he allowed himself to become one, he did not resist. It was not that he lacked conscience; he smothered it. It was not that he lacked sensibility; he coarsened it. It was not that he lacked humanity; he deadened it. The brute runs to feed Moloch because to him Moloch is not a false god, but a Delightful True Lord, the Master who brings him exaltation. In exaltation he shovels in the babies .... The intelligent man of conscience also shovels in the babies, and it does not matter that he does it without exaltation. Conscience, education, insight-nothing stops him. He goes on shoveling. He knows what wickedness is .... He is a morally sensitive man, and he shovels babies to glut the iron stomach of the idol .... A virtuous future as a model of remorse lies ahead of him; he shovels. He shovels and shovels, all the while possessed of a refined and meticulous moral temperament-so refined and so meticulous that it knows the holy power of forgiveness and knows to ask for it .... Let the SS man die unshriven. Let him go to hell. Sooner the fly to God than he. ${ }^{7}$

(1972), reprinted in ETHICS AND PERSONALITY 207 (John Deigh ed., 1992). I no longer endorse all the claims made in this essay, but I would like to think that it still contains some insights.

7 Simon Wiesenthal, The Sunflower 209-10 (rev. \& expanded ed., 1997). In this book Wiesenthal recounts his experience of a dying SS soldier who asked him for forgiveness. Wiesenthal shared that story with various people (writers, theologians, philosophers, etc.) and asked them to write brief essays in order to answer the question of what, in their view, Wiesenthal's response should have been. 
These are powerful words that should pull us up short and provide an opportunity for deep reflection. However, although I think that Ozick is on to something, her observations strike me as insufficiently nuanced to capture the whole story. Consider the "opportunistic" cooperator in evil. Wilhelm Furtwängler, the eminent conductor of the Berlin Philharmonic during much of the Nazi period, might be an example here. Suppose, as some people have claimed, he remained in Nazi Germany in considerable awareness of the evil of the Nazi regime, knew that his remaining allowed the Nazis to use him as a powerful symbol, and remained there mainly out of ambition and vanity-the fear that, if he left, someone else, the one he contemptuously called "little K" for example, might replace him as the leading star of German orchestral music. ${ }^{8}$ Or consider Adolf Eichmann as a much more dramatic example. Suppose that, as Hannah Arendt suggested, he assisted in the Holocaust, not out of much genuine conviction, but mainly as a method of career advancement-thereby illustrating what she famously called "the banality of evil." " With respect to people of this nature, I am inclined to sympathize with Ozick and, at least as my first thought, think that had they offered any apologies, expressions of remorse, or pleas for forgiveness (they in fact did not) this might well be regarded, as the saying goes, as "a day late and a dollar short." Why? Because they surely knew full well the nature of the evil enterprise in which they were complicitous and either did not care or culpably deceived themselves about it simply in order to advance their self interest.

Karl's story strikes me as perhaps a story of a very different sort, however. Given his youth and the susceptibility of youth to peer pressure, given the fact that he came to his adolescence at a time when most people in Germany were being charmed by National Socialism, and given that membership in the Hitler Youth was at that time almost socially mandatory for young German males, it is at least possible that Karl was not fully aware at the time he acted that he was advancing evil but did, at a later time and on more mature reflection, lose his "innocence," come to see the evil of what he had done, and become genuinely remorseful. It is not at all clear, at least to me, that he performed his evil actions with full knowledge and out of self interest. Rather it seems that he may have been acting out of principles - evil principles, to be sure, but ones that he perhaps could not see as evil until he actually saw and participated in unspeakable acts that he had only before thought of in abstract terms. Perhaps, in the

8 Furtwängler, although perhaps the greatest conductor of his generation, had a petty streak that made it difficult for him to express admiration for any other conductor. (His expressed opinions of Toscanini, for example, were outrageous.) He particularly feared being moved aside by younger German conductors-particularly by Herbert von Karajan, whom Furtwängler contemptuously referred to as "little K." (Furtwängler was quite tall, von Karajan rather short.) The Nazis could sometimes get Furtwängler to conduct on occasions with a dramatic Nazi presence (occasions he seemed to want to avoid) by telling him that if he would not conduct, then the authorities would engage von Karajan. A very entertaining way to learn a few basic things about the controversies concerning the degree of Furtwängler's cooperation with the Nazi government is to be found in the play Taking Sides by Ronald Harwood. Much of the dialogue of this play (made into a fairly decent film, by the way) is drawn from transcripts of Furtwängler's Denazification hearings.

9 HANNAH ARENDT, EICHMANN IN JERUSALEM: A REPORT ON THE BANALITY OF EVIL (1963). 
moral realm, knowledge by description must sometimes be supplemented by knowledge by acquaintance. Thus I am reluctant to lump him in with Furtwängler and Eichmann and simply assume that any remorse he expressed must be morally irrelevant to our ultimate assessment of his character and desert. So, unlike Ozick, I would not so quickly put the fly in front of Karl on the road to God. ${ }^{10}$

Most people would, I suspect, defend - for the reasons given above or for other reasons - - a view directly opposed to Ozick's - would argue indeed that repentance and remorse, at least with respect to some individuals, are among the best reasons one could have for granting mercy. Sister Helen Prejean, for example, has been highly critical of George W. Bush's decision (when he was Governor of Texas) not to grant clemency to Karla Faye Tucker-a death row inmate who had converted to Christianity and who seemed to be genuinely repentant and to exhibit remorse for what she had done. Suspecting that Bush's decision in this case revealed that his claim to be a Christian was either ignorant or insincere, she has this to say about him and his decision:

Here was Karla Faye, a woman who had transformed her life and would have been a source of healing love to guards and prisoners for as long as she lived, yet the iron protocol of retributive justice demanded that she be put to death ... . I I already knew the substance of Bush's position toward Karla Faye, but [when I heard him say] "May God bless Karla Faye Tucker and may God bless her victims and their families" ... my anger at George W. Bush turned to outrage . . . I had to struggle to keep a vow I made to reverence every person, even those with whom I disagree most vehemently. Inside my soul I raged at Bush's hypocrisy ... [I tried] to reign myself in, I took a deep breath, said a fierce prayer, looked into the camera and said "It's interesting to see that Governor Bush is now invoking God, asking God to bless Karla Faye Tucker, when he certainly didn't use the power in his own hands to bless her. He just had her killed."11

10 Actually, I am increasingly reluctant to endorse any judgments about the final worthlessness of any human being-even the Eichmanns of the world. This is why, in discussing Furtwängler and Eichmann, I said that my first (but not necessarily my last) thought was to apply Ozick's dismissive analysis to them. For some of the reasons behind the softening of retributive views $I$ have previously defended in such matters, see my Legal Moralism and Retribution Revisited, in 1 CRIMINAL LAW AND PHILOSOPHY 5 (2007). This was my 2006 Presidential Address to the American Philosophical Association, Pacific Division, and has also appeared in 80 ProceEdings AND AdDRESSES OF THE AMERICAN PHILOSOPHICAL AsSOCIATION 45 (2006). For rich discussions of how we might come to see precious humanity even in those who have performed acts of great evil-discussions to some degree inspired by Simone Weil-see RAIMOND GaITA, GoOD AND EVIL: AN ABSOLUTE CONCEPTION (2d ed.

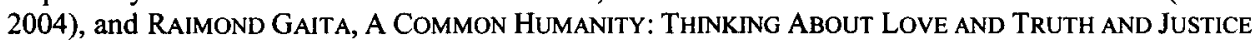
(2000). For a rich essay exploring the way in which a "stain on the soul" can remain even on a repentant wrongdoer, see Eleonore Stump, Personal Relations and Moral Residue, in HISTORY OF THE HUMAN SCiEnCES: Theorizing From the Holocaust-What is to Be Learned? 33 (Paul Roth \& Mark S. Peacock eds., 2004).

11 Sister Helen Prejean, Death in Texas, N.Y. REv. Books, Jan. 13, 2005, available at 
Earlier in the same essay, Sister Prejean summarizes the case she had made in favor of merciful clemency for Karla Faye Tucker:

Yes, [she was] guilty of a horrible crime-she killed two helpless people with a pickax-but she seems genuinely remorseful for her crime; she seems to have undergone a genuine life-changing religious conversion. Even the warden and corrections officers attest that for fourteen years she's been a model prisoner. Couldn't she spend the rest of her life helping other prisoners to change their lives? Is a strict "eye for an eye" always called for? ${ }^{12}$

In this essay, I propose to examine the concepts of apology and remorse, explore some of their moral and epistemic dimensions, and finally discuss whether they have any legitimate role to play in showing mercy. I have previously written about remorse and apology in connection with criminal sentencing, and I will here revisit some of the ideas I presented in those writings-will even steal most of the text from one of them-but will substantially modify (even abandon) some of those ideas and extend some of them into other areas of criminal law where mercy may be thought appropriate-in particular, the area of executive clemency. ${ }^{13}$ I will argue that the moral issues raised by apology and remorse are roughly the same in both sentencing and clemency decisions, but that the epistemic situation in the two areas may differ substantially.

http://www.nybooks.com/articles/17670 (Sister Helen Prejean describing, in a 2005 essay, her earlier futile struggles to save the life of Karla Faye Tucker.). I would not presume to speculate on the sincerity of President Bush's claimed commitment to Christianity. It is worth pointing out, however, that Sister Prejean is confused here. One cannot legitimately infer from the fact that a person believes that a criminal deserves the secular death penalty the conclusion that this person cannot consistently hope for the salvation of the soul of the criminal who is executed - the meaning surely of "may God bless" in this context. Were all judges who closed their sentences of death with "and may God have mercy on your soul" being confused or hypocritical? I think not.

12 Id.

13 The essay (a transcript of a public lecture) on which I am mainly drawing is Well Excuse Me! Remorse, Apology, and Criminal Sentencing, 38 ARIZ. ST. L.J. 371 (2006). It is an occasion of some embarrassment to me that in the present essay I am correcting a major mistake in an essay that appeared so recently. I am not sure why my insight into the need for a correction did not come earlier, but I am inclined to blame Michael White for not noticing the mistake when he read the earlier essay-a mistake for which he has, of course, to some degree atoned by catching it this time around. (The mistake, to be discussed in detail later, concerns the issue of the degree to which apologies are performative utterances.) In the present essay I have also drawn on my Repentance, Punishment, and Mercy, in REPENTANCE: A COMPARATIVE PERSPECTIVE 143 (Amitai Etzioni \& David E. Carney eds., 1997) [hereinafter Murphy, Repentance, Punishment, and Mercy]. 


\section{A PRELIMINARY DIGRESSION}

Prior to my primary discussion, there are two points I would like briefly to discuss: (1) an ambiguity in the concept of remorse and (2) the difference, not always appreciated, between religious conversion and remorse.

\section{A. Two Kinds of Remorse}

In an earlier essay, understanding remorse simply to be feelings of guilt over wrongdoing, I characterized repentance in the following way:

Repentance is the remorseful acceptance of responsibility for one's wrongful and harmful actions, the repudiation of the aspects of one's character that generated the actions, the resolve to do one's best to extirpate those aspects of one's character, and the resolve to atone or make amends for the harm that one has done. ${ }^{14}$

I still think that this analysis of repentance is generally in the right ballpark, but I have now come to realize that the concept of remorse involves a complexity I had not previously appreciated, a complexity that shows that in at least one of its forms it should not simply be identified with guilt. In other words, I will note a way in which the word "remorse" is ambiguous.

Consider the unjustified and unexcused breaking of a reasonably important promise - one of significance to the person to whom the promise has been made, but not one the breaking of which will cause irrevocable harm to that person. In such a case, some non-trivial guilt feelings would surely be expected of a morally serious person, but many would be reluctant to use the word "remorse" to capture these feelings-preferring to reserve the word "remorse" to capture those extremely powerful guilt feelings that are appropriately attached only to grave wrongs and harms. Indeed, for a person to feel and express remorse over wrongs or harms that are less than grave might well strike many, not as a sign of moral seriousness, but simply as neurotic-non-neurotic remorse involving great and powerful guilt only in cases where this is proportional to what has been done.

The difference between some cases of remorse and other instances of guilt is not simply a matter of degree, however. This is because I have come to think that a kind of hopelessness is essential to the inconsolable bite of conscience-what some medievals called the agenbite of inwit - that is the essence of one kind of remorse. This kind of remorse, although having powerful guilt feelings as a component, seems

14 Murphy, Repentance, Punishment, and Mercy, supra note 13, at 147. Purely for the sake of simplicity, I will sometimes in the text use "remorse" and "repentance" interchangeably. Speaking strictly, however, it should be noted that-as indicated here-remorse is only one component (though in my view the most important one) of full repentance. I believe that the resolve to reform oneself and to make amends are also important components of full repentance. 
to involve more than guilt - seems to involve the idea that the wrong one has done is so deep, has involved such a wanton assault on the very meaning of a person's human life, that one can in no sense ever make it right again-such a possibility being permanently lost. Breaking a promise is typically not a wrong of this nature. Blinding a person is-as is murdering a person or that person's beloved child. Rape and torture also come to mind as other examples. In these cases one has inflicted such a moral horror on one's victim that he or she may never again have a secure grasp of their place in the world or of the meaning of their lives. ${ }^{15}$

And what would atonement look like in such extreme cases? Certainly not compensation in the sense of a tort law remedy-e.g., financial sacrifice in the payment of damages - since the very idea of making the victims whole again, returning them to status quo ante, may be so obviously impossible that the very suggestion seems obscene. In these cases, the best that one might be able to do in the way of atonement would be an extreme form of penance-e.g., Stavrogin's suicide (in Dostoevsky's novel The Devils) or Father Sergius' cutting off his finger with an axe (in Tolstoy's story "Father Sergius"). ${ }^{16}$ Even then, however, even if one tried to impose on oneself some "eye for an eye" suffering as intense as the suffering one has caused, could one ever put the wrong fully behind one and honestly say "now I have made it up, can forget about it, and simply get on with my own life"? Probably not. This may be in part because whatever suffering one imposes on oneself is a result of one's own choices-something that victims cannot say of themselves with respect to the suffering imposed on them. Even in extreme self-imposed penance, penance of great suffering, one still retains an autonomy that one has denied to one's victims. Thus, no matter what one might do, one could never fully get right with victims of this nature. ${ }^{17}$ (Whether one could ever get right with God after such atrocities is a different matter. $)^{18}$

15 The concept of "moral horror" has been richly explored by Robert Merrihew Adams in his book FINITE AND INFINITE GOODS (2003), and the related concept of "horrendous evil" has been richly explored by Marilyn McCord Adams in her book HoRRENDous EvILS AND THE GoODNESS OF GOD (1999).

16 I do not mean to suggest that the sole explanation of Stavrogin's suicide is an expression of remorse and an attempt at penance. Some competing Nietzschean fantasies of heroic will are also at work in this complex and troubled character. I am grateful to Stephanos Bibas for discussion of this novel.

17 ' $[$ I] $]$ the case of remorse, 'there are no set ways to remedy evil.' One has destroyed an object of value and this destruction may be, precisely, irremediable." Alan Thomas, Remorse and Reparation: A Philosophical Analysis, in REMORSE AND REPARATION 127, 130 (Murray Cox ed., 1999). Thomas is quoting from John Deigh's important essay "Love, Guilt, and the Sense of Justice" from Deigh's essay collection THE Sources of MORAL AgENCY: EsSays IN MORAL Psychology AND Freudian TheORy (1996).

18 Our secular concepts of repentance and remorse no doubt have at least part of their origin in religion, but the secular meaning of those concepts can differ substantially from at least some religious meanings. From a purely secular perspective, it does indeed seem odd to think that remorse might legitimately attach to both trivial wrongs and serious wrongs. From some religious perspectives, however, all sins might be viewed as affronts to God and thus equally serious and demanding the same 
The points I want to make in the main body of this essay will rarely require my distinguishing between the two kinds of remorse that I have highlighted, and-unless otherwise noted-I will generally use the word "remorse" in such a way as to elide the distinction. When there is an ambiguity in our language, however, as I have suggested there is with the word "remorse," this sometimes points to a difference in concepts. Thus the distinction between two kinds of remorse seems to me worth making if only in the interest of total conceptual clarity. Even if the distinction will not do much work in the present context, it might do considerable work in another and will thus be useful to keep at least in the back of one's mind.

\section{B. Religious Conversion, Repentance, and Remorse}

It is very commonly thought that religious conversion is closely linked to remorse over and repentance of criminal wrongdoing-perhaps even a necessary condition for the latter two or even equivalent to them.

This way of thinking is mistaken. A genuine religious conversion would surely lead to remorse over and repentance of one's sins, but this does not entail that the concept of sin involved will be equivalent to criminal wrongdoing. Suppose someone of a totally secular frame of mind becomes a terrorist engaged in the criminal killing of innocent people as a way of supporting Palestinian liberation-a cause he supports for purely secular political reasons. Further suppose that at some later time he converts to radical Islamic fundamentalism. It is likely that, rather than repenting of his acts of terrorism and feeling remorse over them, he will be even more convinced than before that he has been engaged in a righteous cause-a cause now viewed as righteous on both secular and religious grounds. This example should show that the concepts of religious conversion and repentance/remorse, although sometimes and perhaps even often causally linked, are not equivalent. Nor is one a necessary or sufficient condition for the other. Sincerely religious people can be utterly unrepentant for (at least some of) their crimes, and some sincerely repentant people can be totally non-religious or even anti-religious.

A related point I will here state simply as a guess since I am not sufficiently studied in evangelical Christianity to have an expert opinion on the matter: Many evangelical Christians speak of their conversion experiences as being "born again" and describe themselves as starting with a clean slate, as "beginning again." On one interpretation of this way of talking, it seems to me that one might be encouraged not to spend much time looking to or thinking about the past (and remorse involves rather consuming thinking about the past) because, having now been saved by perceiving the direct intervention of Jesus into one's life, one is now in some sense a "new person"not the same person who committed those terrible past criminal acts. Indeed, an

level of remorse. Also God's ability to forgive may be infinite in a way that it would be unreasonable to think likely for mere human beings. So even if getting right with my neighbor may sometimes be impossible, no matter how much remorse I feel, getting right with God may still be regarded as possible. Indeed, to believe otherwise is often regarded as the unforgivable sin of despair. 
excessive brooding over one's past sins, particularly if it results in the kind of hopeless and inconsolable remorse I discussed above, may approach the sin of despair, the sin of believing that God's forgiveness and love is forever lost. This sin, very likely the one exhibited by Judas when he hanged himself, is the one sin that is often regarded as unforgivable.

But perhaps all my example shows is the mysteriousness-even incoherence-of "new person" talk if such talk is taken at all literally.

Now that these two preliminary points are out of the way, let me move to the primary question of my essay: What legitimate role, if any, should remorse or apology on the part of the wrongdoer play in the administration of legal punishment and legal mercy?

\section{REMORSE AND THE CULTURE OF APOLOGY}

Must successful apology always be linked with remorse? Surely not. For small wrongs, the mere verbal formulae "I apologize" or "I am sorry" or "Forgive me" or "Excuse me" are generally adequate since their only function is to keep oiled the wheels of civility and good manners. What works for small wrongs is likely to be quite unacceptable for wrongs of greater magnitude, however. For grave wrongs, we-both victims and spectators-normally expect more than a verbal formulaperhaps nothing as extreme as Stavrogin's suicide or Father Sergius's cutting off his finger with an axe, but we expect something more than mere apology as a formality. Here we normally expect such things as repentance, remorse (in at least one of its forms), and atonement; and we are interested in apologies only to the degree that we believe that they are sincere external signs of repentance and remorse and reliable external signs of future atonement.

One of the things I intend to do in this essay is to explore the relationship between apology and these other states. Herbert Morris once published a wonderful essay with the title "The Decline of Guilt" could have been "The Decline of Remorse"-a decline that I believe is revealed, paradoxically enough, in the increasing prevalence and even celebration of public apology that we find in early $21^{\text {st }}$ Century America. We now live in what has been called the "new culture of apology"20 - a cultural movement so pervasive that at least one novelist, Jay Rayner, has found it worthwhile to write a satirical novel (Eating Crow) about it—a novel that begins with an apology for the book itself:

I am sorry you bought this book. If it was given to you as a gift, then technically I am not required—or even entitled — to apologize to you. My

19 Herbert Morris, The Decline of Guilt, 99 ETHICS 62 (1988), reprinted in ETHICS AND Personality, supra note 6, at 117.

20 Nicholas Mills, The New Culture of Apology, DisSENT, Fall 2001, at 113. 
apology should go to the original purchaser and they, in turn, should say sorry. ${ }^{21}$

Some people, of course, find the growing culture of apology a very good thing, whereas others-and I count myself among them-fear that it may be little more than a sign of what theologians have called "cheap grace." Those who defend the development will typically see it as advancing general social utility and progress, goals that will be retarded if we remain stuck in the past. "Let bygones be bygones, says Werner von Braun" as the old Tom Lehrer song has it.

Bad people, it should be noted, are often quick studies of social trends that can be used to their advantage, and so it is now not uncommon to find such phrases as "it is time to get this all behind us and move forward" or, more recently, "let's not play the blame game" shamelessly and almost instantly on the lips of wrongdoers-often those in high political office. And those who speak this way--or buy it from others who speak this way - either do not notice or do not care that this way of responding to wrongdoing gives no weight at all to such values as truth or justice or genuine character reformation. Indeed, the more that people lap up this sort of thing, the more are wrongdoers tempted to celebrate their own corruption. Mindful of the old proverb "It is hard to beg forgiveness, but not as hard as asking permission," these wrongdoers may even take delight in their opportunity to apologize-as revealed in this New Yorker cartoon: ${ }^{22}$

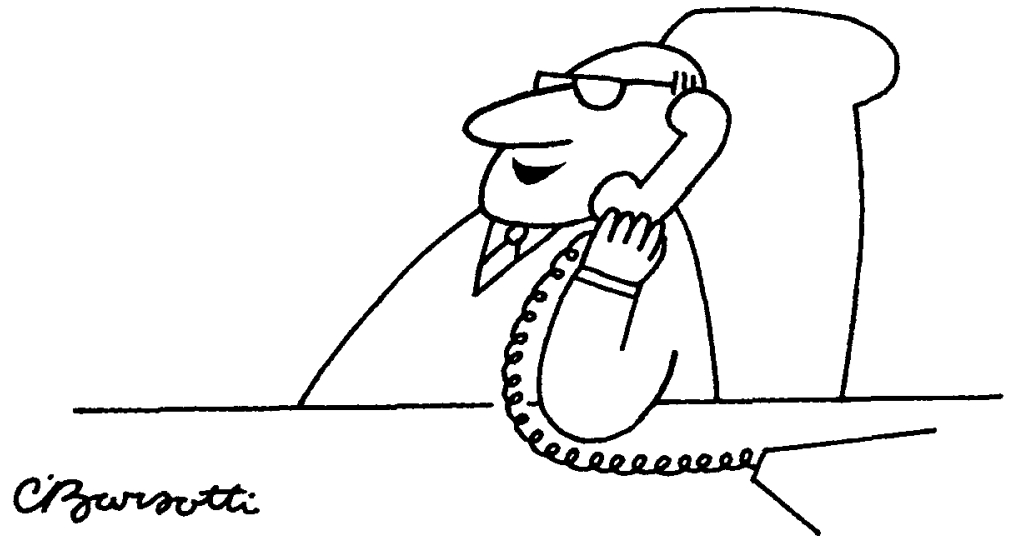

“Hi, hon. Guess who's going to be on national television apologizing to the American public."

21 JAY RAYNOR, EATING CROW 1 (2004).

22 - The New Yorker Collection 2000 Charles Barsotti from cartoonbank.com, published in The New Yorker on Oct. 16, 2000. All Rights Reserved. Used by permission. 
Such a celebration of form over substance is not always defended merely on grounds of progress and general utility, however. It may also be defended on moral or religious grounds or on grounds of mental health.

Here, for example, is a piece of idiocy about apology—one that deprives it of any useful meaning - cloaked in the language of idiotic theology. I quote it from the magazine The Living Church, self described as "An independent weekly serving Episcopalians." In a column devoted to "Advent Preparation," this theological gem occurs in what is supposed to be a commentary on the readings for the first Sunday in Advent:

We're prepared to meet the Lord to the extent that we live out his kingdom's values here and now. We're to honor and respect one another without qualification. We're to apologize when we offend the sensibilities of our sisters and brothers, even when they know we haven't done wrong. ${ }^{23}$

Surely we should ask a few skeptical questions before pledging our allegiance to this piece of treacle. If I have done nothing wrong, then what exactly am I supposed to be apologizing for? "Offending their sensibilities" it would seem. But what if they are wrongly sensitive, being offended by what is simply honest criticism -as (for example) poor students often are, desperately wanting some explanation other than their own lack of ability or preparation for their failures? I should be apologizing to them? I think not. The suggestion that I should is simply some mixture of mushy sentimentality and political correctness masquerading as theology and morality. I am reminded here of the way that The Living Bible, often an unintended source of theological humor, renders "Judge not that ye be not judged" at Matthew 7:1 as "Don't criticize, and then you won't be criticized."

Added to arguments of social utility and theology are, as we might expect in our present therapeutic culture, arguments grounded in trendy notions of mental health where such gems of psychobabble as "closure" and "a time for healing" are the order of the day. So sloppy, indeed, is the current state of theology and morality that these shibboleths of pop psychology sometimes simply pass as theology and morality. Even Bishop Desmond Tutu, generally a man of wisdom and charm, frequently heaps praise on the spiritual and mental health he sees exhibited by those who accept the "reconciliation" offered by the South African Truth and Reconciliation Commissionperhaps without realizing that this seems to suggest, at least by implication, that those who do not wish to reconcile with those who victimized them may suffer from some kind of moral and psychological failing. And this is not even a failure on their part to accept an apology, since the guards and jailers who appeared before the Commission were not required to apologize as a condition of amnesty for their atrocities--for example, the torture and murder of those imprisoned by the apartheid government. 
My reader can certainly see by now that I am inclined to throw something of a wet blanket over the hasty and undue celebration of apology that is current in our culture, and in what follows I will attempt to develop, to the degree that topic and space limitations allow, a more careful and nuanced discussion of what I have so far merely sketched.

\section{REMORSE, REPENTANCE, AND PUNISHMENT}

Since this is a symposium that is focused on the possible roles of mercy in the criminal law, I will obviously not be able to explore all the current important cultural issues with respect to apology and remorse. I will not, for example, explore the odd fact-called to my attention by both Herbert Morris and Margaret Walker- that the mania for public apology in legal and other institutional settings coexists with a frequent unwillingness of people to apologize in the setting of intimate personal relationships. I will not even explore all the current important legal issues-many of which emerge in tort law ${ }^{24}$-and some involving the very complex matter of groups apologizing and expressing remorse to other groups. I will confine myself to criminal law and even here my discussion will be limited in the main to remorse and apology with respect to serious felonies. I have no hope of settling anything in a brief essay, but I will offer a few observations in the hope that they might stimulate productive thought and conversation —or at least provide a useful framework for such thought and conversation. A detailed argument in defense of an expanded role for apology in all aspects of criminal law can be found in a recent essay by Stephanos Bibas and Richard A. Bierschbach, ${ }^{25}$ and I have-earlier in this essay-cited some real world examples in which apology or remorse (or their absence) have had legal relevance in the criminal law, either as arguing for mercy or arguing against mercy. I will begin my discussion here, however, by taking an example from a work of fiction.

David Lurie, the central character in J. M. Coetzee's novel Disgrace, has admitted sexual harassment of a student but could save his job if he simply apologized and expressed the kind of repentance and remorse demanded of him by the university disciplinary board that has punitive authority over him. In refusing to give them what they want, he says the following:

[W]e went through the repentance business yesterday. I told you what I thought. I won't do it. I appeared before an officially constituted tribunal, before a branch of the law. Before that secular tribunal I pleaded guilty, a secular plea. That plea should suffice. Repentance is neither here nor there.

24 Lee Taft, Apology Subverted: The Commodification of Apology, 109 Y ALE L.J. 1135 (2000). Taft's skepticism about apology in tort law inspired me to turn my own skeptical eye to apology in criminal law.

25 Stephanos Bibas \& Richard A. Bierschbach, Integrating Apology and Remorse into Criminal Procedure, 114 YALE L.J. 85 (2004). This is the most detailed and persuasive case for an expanded role for apology in criminal law that I have encountered. 
Repentance belongs to another world, to another universe of discourse .... [What you are asking] reminds me too much of Mao's China. Recantation, self-criticism, public apology. I'm old fashioned, I would prefer simply to be put against a wall and shot. ${ }^{26}$

What I find most interesting in this passage is Lurie's identification of the mechanism of legal or quasi-legal punishment as secular and his claim that talk of repentance, remorse, and apology has no business in such a secular context. His point, presumably, is that these concepts-particularly the concepts of remorse and repentance-are at their core religious concepts and that their introduction into a secular context is radically misplaced.

Why might one think this? One possibility is the belief that repentance and remorse are conditions of one's very soul and that the secular state acts wronglyperhaps even impiously - in presuming to inquire into such private matters and to make secular punishment depend on secular guesses about when these states of character or soul are present. These are, one might think, private religious or spiritual matters between a person and one's God, matters that might be corrupted if the outcome of legal proceedings could depend on them. Indeed, desires for legal leniency might tempt one into sin-into confusing genuine repentance with soul damaging fakery, hypocrisy, and self-deception. So concerned was ancient Jewish law to avoid such temptations to sin, indeed, that even confessions, and not just apologies and expressions of remorse, were inadmissible in criminal proceedings. ${ }^{27}$ It has also been argued that our own constitutional protections against self-incrimination may have some similar religious foundations. ${ }^{28}$

Another related consideration here is that issues of deep character are matters about which the state is probably incompetent to judge-it cannot even deliver the mail very efficiently, after all - and which, for that reason and others, might well be regarded as simply none of the state's business. On one fairly traditional understanding of the liberal state, for example, it is legitimately concerned with prohibiting acts that are not in conformity with its public rules but treads on dangerous ground if it seeks to inquire too deeply into the private attitudes that offenders have when they manifest non-conformity. The liberal state might legitimately explore such mens rea conditions as intention, since these define the prohibited act itself; but inquiring into deep character, perhaps even motive on some understandings of that concept, may be viewed as going into matters beyond its legitimate scope.

It is not just liberals and secularists, however, who worry about the issues raised above. Queen Elizabeth I, for example-hardly a liberal and hardly a secularistsurely had some of these concerns in mind when, in imposing the Settlement that

26 J. M. COETZEe, DisGrace 58, 66 (1999).

27 Cheryl G. Bader, 'Forgive Me Victim for I Have Sinned': Why Repentance and the Criminal Justice System Do Not Mix-A Lesson From Jewish Law, 31 FordHAM URB. L.J. 69, 70 (2003).

28 Robert S. Gerstein, Privacy and Self-Incrimination, 80 ETHICS 87 (1970). 
stabilized the Church of England, she said, "I would not open windows into men's souls." Elizabeth's primary worry was no doubt prudential- - her realization of how speculations about the interior lives of various of her subjects could easily become hostage to disruptive political factionalism. Her worries might have been religious as well, however, since deeply religious people who place great weight on the religious significance of repentance and remorse or other inner states of character might oppose blending such matters with criminal law not because they do not value them but rather because they value them so very much — so much that they do not want to risk having them tainted by secular legal mechanisms. Such blending might work out splendidly in Dostoevsky novels but work far less splendidly in the messy real world of actual criminal law, a world in which what passes for justice is administered by always fallible, often fearful, and sometimes cruel and corrupt human beings. You will not, I suspect, find very many contemporary American criminal prosecutors who, like Dostoevsky's Porfiry Petrovich, have a deep, honest, and informed concern with the spiritual reclamation of the criminals whom they must pursue, arrest, and bring to trial; and I am not at all sure that our society would or should welcome anyone who would presume to be such a prosecutor.

Let us grant, then, that Coetzee has, through his character of David Lurie, revealed some spiritual and even political dangers that can be present when religious concepts of remorse and repentance are brought into secular tribunals. To the degree that he is suggesting that all concepts of remorse and repentance are religious in nature, however, then it seems to me that he is simply mistaken.

Remorse (as bad conscience) is, as I have argued elsewhere, often best understood as the painful combination of guilt and shame that arises in a person when that person accepts that he has been responsible for seriously wronging another human being - guilt over the wrong itself, and shame over being forced to see himself as a flawed and defective human being who, through his wrongdoing, has fallen far below his own ego ideal. ${ }^{29}$ Shame should provoke repentance - the resolve to become a new and better person-and guilt should (where this is possible) provoke atonementembracing whatever personal sacrifice may be required to restore the moral balance that one's wrongdoing has upset and to vindicate the worth of one's victim, a worth that one's wrongdoing has symbolically denied. This may be a sacrifice of liberty or even life (a punishment in proportion to the wrong one has done) or it may be a sacrifice of resources-e.g., the paying of restitution. "Put your money where your mouth is" is, I think, a cliché with legitimate bite, since the willingness to make sacrifices is a relevant if not conclusive test of sincerity.

Why, one might ask, are such remorse and repentance of value and worthy of our respect? One of the reasons is, of course, found in those religious perspectives previously discussed but is not limited to them. Even the atheist can believe that the person who is sincerely remorseful and repentant over his wrongdoing exhibits a better and more admirable character than a wrongdoer who is not repentant. Cynthia

29 See Jeffrie G. Murphy, Shame Creeps Through Guilt and Feels Like Retribution, 18 LAW \& PHIL. 327 (1999). 
Ozick to the contrary, most of us probably believe that simply having a character properly connected to correct values, even if late in coming, is an intrinsic goodsomething worthy of our respect quite independently of any external consequences it may have. Remorseful persons can also serve as "models of remorse" (to use Cynthia Ozick's phrase against her)_-models of what is humanly possible in the realm of selftransformation, models that will perhaps make us less discouraged in our hopes for our own moral and spiritual progress. ${ }^{30}$

Remorse and repentance may also have useful social consequences, and these may matter as well. It is often said, for example, that people who are remorseful and repentant are less dangerous, less likely to do wrong again, than those who are unremorseful and unrepentant. I hope that this is true, but I am not sure. The wrongdoer can be self-deceptive or just honestly mistaken about the sincerity of his own repentance, and even the sincerely repentant wrongdoer can suffer from weak will. It is not for nothing that the term "backsliding" plays a role in both our moral and religious vocabularies, and the concept of weakness of will (akrasia) has produced a vast body of philosophical and religious writing. Surely Jesus' disciples were sincere when they promised to stay awake and keep watch while he prayed at Gethsemane, but he found them asleep and could only observe "the spirit is willing but the flesh is weak."

Another external consequence worth noting is one that may have its most meaningful impact on victims. As I have argued elsewhere, ${ }^{31}$ a wrongful act is, among other things, a communicative act. When one is wronged by another, a nontrivial portion of the hurt may be the receipt of an insulting and degrading symbolic message delivered by the wrongdoer, the message "I matter more than you and can use you, like a mere object or thing, for my own purposes." The repentant person repudiates this message, stands with his victim in its repudiation, and acknowledges moral equality with the victim - an equality denied by the wrongdoing. It is for this reason that repentance may open the door to forgiveness. If one forgives the unrepentant wrongdoer, then one risks sacrificing one's own self respect through complicity in or tacit endorsement of the insulting and degrading message contained in the wrongdoing. A repentant wrongdoer, however, eliminates at least this one obstacle to forgiveness. To the degree that the whole community, and not just the individual victim, is a victim of criminal wrongdoing, then repentance on the part of the wrongdoer can have symbolic significance for the community as well.

But even if repentance is a great moral and spiritual good-one carrying both actual and symbolic significance-it does not follow, given the limitations of the secular state, that it should play any significant role in the criminal law. Repentance may make victims feel better, and rightly so, but it is by no means clear to what degree, if any, the system of criminal law should be driven by the goal of victim

30 I am grateful to Ellen Cancakos for this insight about the way in which seeing selftransformation in others may assist us in gaining confidence for our own attempts in this regard.

31 Jeffrie G. Murphy, Forgiveness and Resentment, in FORGIVENESS AND MERCY 14-34 (1988); JEFFRIE G. MURPHY, GETTING EVEN: FORGIVENESS AND ITS LIMITS (2003). 
satisfaction. Perhaps it should be, but that-as revealed in the leading victim impact statement cases-is controversial. ${ }^{32}$

Another real problem here is not theoretical but is practical, and how one deals with it may depend on one's general attitude toward the human world-on whether that attitude is largely trusting or largely suspicious. The practical problem is obvious-namely, the perpetual possibility of self-serving fakery on the part of wrongdoers. As Montaigne observed, there is "no quality so easy to counterfeit as piety"33 - an observation echoed, so I have been told, by a Hollywood mogul who said this of sincerity: "Sincerity is the most precious thing in the world. When you have learned to fake that, you've got it made."

So a practical problem with giving credit for remorse and repentance is that they are so easy to fake; and our grounds for suspecting fakery only increase when a reward (e.g., a reduction in sentence, clemency, pardon, amnesty, etc.) is known to be more likely granted to those who can persuade the relevant legal authority that they manifest these attributes of character. To the degree we give rewards for goodness of character, then to that same degree do we give wrongdoers incentives to fake goodness of character. One might even suspect, indeed, that the truly remorseful and repentant wrongdoer-particularly one whose remorse is of the second kind noted previously - would not seek a reduction in punishment but would rather see that punishment as one step on a long and perhaps endless road of atonement. Although this is not necessarily the case, the person who asks us to go easy on him because he is repentant may reveal, in that very request, that he is not repentant. And to the degree that we hand out rewards to those who fake repentance and remorse, then to that same degree do we cheapen the currency of repentance and remorse-making us less likely to treat the real article with the respect it deserves.

Worries about fakery and inducements to fakery might have been among the reasons that prompted those who designed the South African Truth and Reconciliation Commission (TRC) not to require apology or expressions of remorse from those seeking amnesty through the Commission. All that was required was full disclosure of wrongdoing and acceptance of responsibility for that wrongdoing. Since the Commission's design was under the strong influence of Anglican Bishop Desmond Tutu, we may be confident that he-as a Christian clergyman - did not leave out apologies or expressions of remorse because he did not value them. More likely, he simply did not want to give incentives to fakery, increase cynicism about such expressions, and thereby devalue the general currency of repentance and remorse. Coetzee, a South African novelist, may well have had that country's TRC in mind

32 In the 1987 case Booth v. Maryland, 482 U.S. 496 (1987), the United States Supreme Court ruled that the use of victim impact statements in capital sentencing is unconstitutional. In 1991 Booth was overruled in Payne v. Tennessee, 501 U.S. 808 (1991). The various judicial opinions on both sides (in both cases) reward study and reflection.

33 Michel de Montaigne, Of Repentance, in THE COMPLETE EsSAYS OF MONTAIGNE 617 (Donald M. Frame trans., 1958). 
when he told the story of David Lurie's refusal to apologize or express remorse before the secular tribunal that had him in its punitive power. ${ }^{34}$

The degree to which expressions of repentance and remorse are to be welcomed as grounds for legal mercy will, of course, depend to a substantial degree on the reasons that incline one to favor criminal punishment in the first place. All of my readers are, I am sure, familiar with the main justifications frequently offered for criminal punishment-deterrence, rehabilitation, and retribution-so let me briefly explore how repentance and remorse might or might not fit into each of these.

If one thinks that the main purpose of punishment is special deterrence, then one will favor counting repentance and remorse if one believes that remorsefully repentant people are less likely to commit future crimes-a controversial claim, surely. Such people may also seem to need less in the way of incapacitation. If one places greater weight on general deterrence, however, one may reasonably believe that this is to some degree undermined if it becomes known that one way to avoid serious punishment is to express repentance and remorse.

What about rehabilitation? This is not much talked about these days, alas, in our rather vindictive and stingy society. If what used to be called "the rehabilitative ideal" does return, however, and if we begin seeking to design penal practices with rehabilitation as a goal, we will probably, as Antony Duff has argued, ${ }^{35}$ want to

34 In commenting on an earlier draft of this essay, Alan Michaels called to my attention the fact that the distinction between acknowledging wrongdoing and the further steps of either repentance or apology may be found, not only in the workings of the South African TRC, but also in the United States Federal Sentencing Guidelines. The most common method by which an offender lowers his "offense level" under the Guidelines is through "Acceptance of Responsibility" under Section 3E1.1 of the FSG. Pleading guilty is almost always both a necessary and sufficient condition for acceptance of responsibility (though technically, it is neither necessary nor sufficient, since the sentencing judge is said, with no clear explanation of what this means, to have some discretion). Remorse, repentance or apology, as opposed to acknowledgment of wrongdoing, are not formally required, or even expressly made relevant. Perhaps this approach of federal law is because of the difficulty of determining the sincerity of repentance and remorse and the likely outcome of the cheapening of apology that might follow from their mere rote offering. On the other hand, there are (as I will note later) some reasons-from both a utilitarian and retributive perspective-why remorse or apology might merit a lower sentence, making federal law's failure to capture these reasons interesting. Of course, it may simply be that the Guidelines are not attentive to many of the distinctions and evaluative judgments noted in this essay. The single mention of remorse in the Commentary is this: "This [downward] adjustment [for acceptance of responsibility] is not intended to apply to a defendant who puts the government to its burden of proof at trial by denying the essential factual elements of guilt, is convicted, and only then admits guilt and expresses remorse." The use of the word "remorse" is interesting here since simple admission of guilt (absent remorse) will normally earn a downward adjustment pretrial, and all the remorse in the world added to post-trial acceptance of responsibility will not result in a downward adjustment. This gives rise to the suspicion that the Guidelines give credit only for pretrial acceptance of responsibility (with or without remorse) because the "mercy" the defendant receives in return is really nothing more than a quid pro quo for saving the government and the witnesses the social costs of a trial, one benefit that is not gained by posttrial acceptance and one that is not a value that we normally associate with mercy when we think of mercy as a moral virtue. The relevant Guideline and Commentary may be found at 18 U.S.C.S. app. § 3E1.1 (2006), available at http://www.ussc.gov/2005guid/3el__l.htm.

35 R.A. DufF, Trials and PUNishments (1986); R.A. DUFF, PUNISHMENT, COMMUNICATION, AND 
structure these practices in such a way that penance, remorse and repentance will be encouraged and rendered more likely-something not likely at all, of course, in the present barbaric conditions found in many American jails and prisons, where such horrors as gang rape are the order of the day. ${ }^{36}$

Some have suggested that religion could be a crucial element in the rehabilitation of criminals. Such "faith based" programs might, however, face some serious constitutional and political problems. Constitutionally, they might run afoul of the Establishment Clause of the First Amendment. Politically, those who initially favor religion in prisons because for them religion is identical with evangelical Christianity may not be happy to support religious programs of rehabilitation where the religion involved is, say, the Nation of Islam - that kind of repentance and rebirth not being their kind of repentance and rebirth. Also, as I noted earlier, religious conversion may not always foster the kind of remorse and repentance that is to be hoped for in a secular system of criminal law.

Suppose for the moment that these objections can be overcome and that serving one's sentence in the right sort of penal environment is indeed a route to a valuable kind of remorse, repentance and rebirth. In such a case, we should I think be particularly skeptical about letting claims of remorse and repentance influence us toward leniency at the time of sentencing, since in the world we are now imagining we will be sentencing people to a kind of punishment that, though it will of course involve the hardship of deserved loss of liberty for them, will also offer them a great good: the possibility of becoming better people. And why would we want to allow the present vice of fake remorse and repentance to deprive us and criminals of the future benefit that a genuinely rehabilitative penal system might confer - the benefit of their becoming better people and better citizens? So, ironically enough, the more that one stresses the reformative value of systems of punishment that will encourage genuine remorse and repentance, the more should one be on one's guard against anythingfake remorse and repentance, for example-that might allow the criminal improperly to avoid such a system or improperly to cut short his time in it.

With respect to clemency decisions, however, the situation in a properly designed rehabilitative world will be quite different. If the goal of the system is itself rehabilitation, and if rehabilitation is thought to be present when remorse and repentance are present, then - when faced with a truly remorseful and repentant prison inmate-it can be seen that the system has done its work and release from criminal custody will clearly be in order. This point only holds in theory for an imagined world of pure rehabilitation, of course, since in the actual world rehabilitative goals, however laudable, will likely compete with other values-deterrence, for example.

Community (2001).

36 See Mary Sigler, By the Light of Virtue: Prison Rape and the Corruption of Character, 91 IOWA L. REV. 561 (2006), for an argument, based in virtue theory, that our acceptance of such a high incidence of prison rape corrupts the characters of inmates and may reveal corruption in the characters of those of us who tolerate it or, in some cases, even make or enjoy jokes about it. 
But suppose that one is not inclined to defend punishment in terms of either deterrence or rehabilitation but is instead a retributivist—one who claims that the purpose of punishment is to give criminals the punishment that they deserve. This claim immediately forces us to ask "What exactly is desert?" If one thinks that desert is a function of the wrongdoing itself and the legitimate grievance that it creates for individual victims and for society at large (grievance retributivism), then one might find it hard to see how grievance is lessened by subsequent repentance. ${ }^{37}$ If someone assaults me and thereby creates in me a legitimate grievance against him, how is that grievance lessened if the wrongdoer later finds Jesus and repents? He may, of course, be a better person because of this, but is my own grievance any less? Is society's? If one thinks that the grievance is in part based on the symbolic message of insult and degradation contained in the wrongdoing, then-for reasons earlier discussed-one might indeed think that a grievance is less after repentance, which represents the wrongdoer's withdrawal of the endorsement of that message. However, to the degree that one thinks that grievance is based on much more than this symbolic message-as it might well be for very grave wrongs and injuries - then repentance simply might not be enough.

Suppose one is not a grievance retributivist but rather subscribes to character retributivism - that is, one believes, with the philosopher Immanuel Kant, that the purpose of punishment is to give people the suffering that is properly proportional to what Kant called their "inner viciousness." ${ }^{38}$ Most of those holding this view (but not the Ozickian holdouts) will be strongly inclined in theory to count repentance and remorse in favor of the criminal, since these states of character, if truly present, will be viewed as revealing an inner character that is much less vicious than the character present in the unrepentant criminal.

Even for the character retributivist, however, there will still be the practical problem earlier discussed of distinguishing the genuine article from the fake. Also, if one is going to count one's judgments about good character in favor of the criminal, then it would seem--in symmetry-one ought also be willing to count judgments of bad character against the criminal. It is interesting in this regard, however, that-at least in my experience-many of those who want to count expressions of repentance and remorse in the criminal's favor are first in line to condemn the use in assigning punishment of claims that the criminal's character is "cruel, heinous and depraved" or reveals a "hardened, abandoned, and malignant heart" - phrases that have appeared in death penalty and other American homicide cases.

37 "Retributivism has a distinct temporal orientation. It looks backward. This simple point has important consequences if the basic goal of the penalty phase is to impose deserved punishment. From a retributive perspective, the punishment a defendant deserves is, to put it somewhat metaphorically, fully congealed at the time of the crime." Stephen P. Garvey, "As The Gentle Rain from Heaven": Mercy in Capital Sentencing, 81 CORNELl L. REV. 989, 1029-30 (1996). Subject to the qualification about symbolic messaging that I will soon note, this claim seems correct for grievance retributivism. There are forms of what I will later call character retributivism, however, that would challenge this claim.

38 See Jeffrie G. Murphy, Does Kant Have a Theory of Punishment?, 87 ColuM. L. REV. 509 (1987). 
Is this lack of symmetry logically inconsistent or irrational in some other way? One might argue that humanity and decency require that one be willing to run more risks on behalf of gentleness rather than on behalf of harshness-a sentiment in line with the venerable slogan that it is better to let guilty people go free than to punish innocent people. I have great sympathy with this line of thought, but it-like the venerable slogan itself-is not self-evident and thus should not be accepted without argument. $^{39}$

Where, then, do I personally stand on the issue of remorse and repentance as grounds for mercy in criminal law? Given that my own nature (alas) tends to be more cynical and suspicious than trusting, my current inclination-although I am still conflicted about this-is not to give much weight to expressions of remorse and repentance at the sentencing stage of the criminal process. I simply see too much chance of being made a sucker by fakery.

With respect to clemency decisions, however, it strikes me that judgments about remorse and repentance may have a much more legitimate role to play. The same noted moral and political values-deterrence, rehabilitation, retribution-are at stake here as are present with respect to sentencing, but the epistemic problems seem-at least to me-less worrisome. Why? Simply because we will have a more reliable evidential foundation upon which to base judgments of sincerity. The writer Florence King, commenting on the Karla Faye Tucker case, gives her reasons for believing that Tucker's conversion was sincere:

Faith, hope, and snobbery aside, I believe Karla Faye's conversion was sincere, in part because the Born Again stance is so exhausting that no one could fake it for very long. Remember, she was Saved in 1985 and spent 12 years witnessing, praising, and thumping, not to mention perfecting the Pat Robertson art of smiling, laughing, and talking at the same time. "Protestantism," said Mencken, "converts the gentle and despairing Jesus into a YMCA secretary, brisk, gladsome, and obscene." Without the lube job of sincerity working in mysterious ways she would have dislocated her jawbone. ${ }^{40}$

39 Stephen Garvey has suggested to me that another way of explaining the noted asymmetrical treatment of good and bad character is to claim that neither is relevant in determining the punishment that the defendant deserves but that both are relevant in decisions to grant or withhold mercy. Since mercy can by nature only result in an actor receiving a lighter sentence, the effect of considering character is necessarily asymmetrical: if the decision-maker decides to grant mercy, the defendant gets a lesser sentence; if the decision-maker decides to deny mercy, then the defendant gets the sentence he deserves. This line of argument assumes, of course, that character is never relevant to desert-an assumption that, as I noted earlier (see Garvey, supra note 37), would be granted by some forms of retributivism but not, I think, by all.

\footnotetext{
40 Florence King, Misanthrope's Corner, NAT'L REV., Mar. 9, 1998, at 72.
} 
And here, in addition to the reasons previously quoted, are some of the other reasons given by Governor Schwarzenegger for not granting clemency to Stanley Williams:

[A] close look at Williams' post-arrest and post-conviction conduct tells a story that is different from redemption. After Williams was arrested for these crimes, and while he was awaiting trial, he conspired to escape from custody by blowing up a jail transportation bus and killing the deputies guarding the bus. There are detailed plans [although never executed] in Williams' own handwriting .... The dedication of Williams' book "Life In Prison" casts significant doubt on his personal redemption. This book was published in 1998, several years after Williams claimed redemptive experience. Specifically, the book is dedicated to "Nelson Mandela, Angela Davis, Malcolm X, Assata Shakur, Geronimo Ji Jaga Pratt, Ramona Africa, John Africa, Leonard Peltier, Dhoruba Al-Mujahid, George Jackson, Mumia Abu-Jamal, and the countless other men, women, and youths who have to endure the hellish oppression of living behind bars." The mix of individuals on this list is curious. Most have violent pasts and some have been convicted of heinous murders, including the killing of law enforcement. But the inclusion of George Jackson on this list defies reason and is a significant indicator that Williams is not reformed and that he still sees violence and lawlessness as a legitimate means to address societal problems. $^{41}$

Although Florence King is being her usual cynical and funny self, and Governor Schwarzenegger is being sober and deliberate, they are both making some similar and important points (whatever one may think of the conclusions drawn from those points in the cases at issue): Those making clemency decisions have a lot more time and a lot more information upon which to base their decisions than would ever be possible given the time and evidential limits imposed on a criminal trial that culminates in a sentence. Mistakes are still possible in clemency decisions - there is never an ironclad guarantee against being deceived by fakery-but the probability of such mistakes is surely reduced by a non-trivial degree. ${ }^{42}$

41 See Statement of Decision, supra note 1. George Jackson was an extremely violent individual-his violence including murder-who, it seems, embraced and celebrated his violence rather than repenting it.

42 Maimonides distinguished coerced from deliberative repentance. The former arises when the conditions for indulging in sinful behavior are no longer present. He called coerced repentance "imperfect" because it does not guarantee a sincere change of heart on the part of the wrongdoer. As such it is contrasted with "perfect" repentance that can only be seen in an environment where it is still possible for the wrongdoer to succumb to the relevant temptation. It is thus hard to see how, on this theory, incarceration could ever provide more than an opportunity for imperfect repentance and thus less than conclusive evidence that the wrongdoer is genuinely repentant. However, if the only way to get conclusive evidence is to put the wrongdoer in an environment in which he could again commit his 
Do these factors weigh differently in death penalty cases than in cases where serious but not lethal punishment is present? I find this a difficult question. On the days (and for me these are most days) when I oppose the death penalty, I tend to oppose it in part because of my own moral and religious convictions about the deep value of remorse-called by Kierkegaard an "emissary from eternity." I want criminals to have sufficient time for remorse, repentance and rebirth and do not want to foreclose this possibility by killing them. The days on which I tend to favor the death penalty, however, are days on which I recall Samuel Johnson's observation that nothing is more effective at concentrating the mind than the prospect of being hanged in a fortnight. Remember the Tim Robbins film Dead Man Walking —often taken and probably intended to be a sermon against the death penalty? What many people seemed to find most moving in the film was the apparent moral transformation of the death row inmate played by Sean Penn. But would this inmate have attained this transformation had he not realized he was facing execution? And would he have retained this transformation if he had at the last minute received clemency? Focusing on this aspect of the film (and on the book by Sister Helen Prejean on which the film was based) one might, somewhat ironically, see the film as making a rather good case in favor of the death penalty. ${ }^{43}$

\section{APOLOGY AND MERCY}

I have up to this point been focusing on remorse and repentance as possible grounds for mercy. Apology has, however, been lurking in the background of my discussion up to this point, but I think that the time has come, in what will be the essay's closing section, for me to say a few more explicit and direct things about it and the role that it might play in decisions to grant or withhold mercy.

The initial point I want to make is to note that apology is something quite different from remorse and repentance. Remorse is an internal mental state and repentance is an internal mental act, both aspects of character that often have external manifestations but are not themselves external. Apology, however, is more complex. In some cases an apology is nothing but a public linguistic performance, a purely external performance that tells us nothing at all about mental states. In other cases,

crime, there are obvious reasons why we would not want to get certainty at this high a price and would rather settle for the best evidence we can get from cases that are imperfect in Maimonides' sense. It would be quite irresponsible, for example, to put-unsupervised-a convicted child molester in an environment of small children in order to make sure that he has his pedophilia under full control. See Pinchas H. Peli, Soloveitchik on RePentance (1984). This is a treatise on Rabbi Soloveitchik's teachings on Maimonides.

43 Consider also Tolstoy's famous novella The Death of Ivan Ilych and ask yourself this question: If, at the last minute, a miracle cure had been provided for Ivan's terminal illness, would the spiritual transformation that he experienced when he accepted that he was dying remain intact? See also the short story $A$ Good Man is Hard to Find by Flannery $O^{\prime}$ Connor in which an escaped criminal, called The Misfit, says this after an old lady has a moment of grace and redemption just before he shoots her: "She would of been a good woman if it had been somebody there to shoot her every minute of her life.' 
however, an apology is something much more than this-a public linguistic performance, to be sure, but one that leads listeners to form legitimate expectations concerning the presence in the apologizer of certain mental states or mental acts, in particular remorse and repentance.

When I first (and, alas, quite recently) wrote on the topic of apology, I suggested that all apologies are what philosopher of language J. L. Austin called "performative utterances," ways of "doing things with words." 44 I have now come to think that this view is mistaken -that only some apologies are performatives in Austin's sense. ${ }^{45}$

According to Austin, if one says "I apologize" or "I am sorry" in the appropriate circumstances - circumstances largely defined by conventional linguistic and social rules-then one has apologized, end of story. In this way "I apologize" is like "I promise" or "I do" (in a wedding ceremony). These words are not representing any mental states-this is the very thing that makes them performative and not descriptive-and thus "I apologize" carries with it no commitment to genuine remorse.

Some apologies are, of course, exactly this and nothing more. These are the kind of apologies that are appropriate for trivial wrongs and social gaffes - for example, accidentally bumping into someone in a crowded hall. Here one says "I apologize"or, more likely, "Excuse me" or "I'm sorry"-merely as counters in social rituals of civility. Indeed, it would actually be quite nuts to feel genuine remorse over something so trivial, and the person who receives and accepts the apology does not expect such remorse-would actually be quite nuts if he did. Can anyone imagine a normal human being in normal circumstances stopping someone who just said "I'm sorry" after a light bump in the hall and conducting an inquiry into the issue of whether the person was sincerely sorry? Surely not.

Of course, if the apologizer visibly crosses his fingers or says "I'm sorry" in an openly sarcastic way, then the "apology" misfires and fails to be an apology since one of what Austin calls the "felicity conditions" of a successful apology performance is that the public performance not include public behavior normally associated with insincerity. But to require, as a condition of successful performative apology, the absence of public behavior normally associated with insincerity is a far cry from saying that a mental state of actual remorse is being described or represented. So in the kind of trivial social contexts here described, I quite agree with Austin that apologies are mere linguistic performatives.

When we come to the context of serious harms and wrongs, however, I now believe that Austin's analysis leads us astray since in these cases our expectations for apologies tend to be far more than linguistic in nature. In these contexts, because of

\section{J. L. AUSTIN, How To Do ThINGS WITH Words (1962).}

45 I owe my enlightenment on this issue mainly to conversations with Michael White, whose knowledge of Austin's philosophy of language is far greater than mine. I have also been influenced by the argument that Lee Taft makes in repenting his earlier view that all apologies are Austinian performatives. See his stimulating essay On Bended Knee (With Fingers Crossed), 55 DePaul L. REV. 601 (2006). 
social rules and conversational implicatures, we take both promises (at least significant ones) and apologies to involve the representation that one sincerely means what one says - that one really is sorry, remorseful, and repentant in the case of apologies and that one really does plan to do what one says one will do in the case of promises. Here one must, in other words, represent that one is sincere. Indeed, in these cases, what we call "the apology" invariably involves, not merely saying "I apologize" or "I am sorry," but also telling a story about one's behavior-a story in which one acknowledges how terrible it was, explains it without seeking to justify it, and conveys the depth of one's sorrow or even self-loathing over it. We would be quite shocked, I think, if a person attempted to apologize for a grave wrong merely by saying "I apologize" and nothing more. That, we would say, was really no apology at all. $^{46}$

It is interesting that Austin missed the importance of seriousness of context with respect to apologies and thus failed to see the distinction between apologies as mere linguistic performatives and apologies that must represent sincerity. In discussing excuses in his famous essay $A$ Plea for Excuses, he noted that certain excuses-e.g. "I did it inadvertently" - that work just fine with respect to fairly trivial matters simply will not do when the matter is serious. He wrote:

[G]iven, I suppose, almost any excuse, there will be cases of such a kind or of such gravity that 'we will not accept' it. It is interesting to detect the standards and codes we thus invoke. The extent of the supervision we exercise over the execution of any act can never be quite unlimited, and usually is expected to fall within fairly definite limits ('due care and attention') in the case of acts of some general kind, though of course we set very different limits in different cases. We may plead that we trod on the snail inadvertently: but not on a baby-you ought to look where you are putting your great feet. Of course it was (really), if you like, inadvertence: but that word constitutes a plea, which is not going to be allowed, because of standards. And if you try it on, you will be subscribing to such dreadful standards that your last state will be worse than your first. ${ }^{47}$

As Austin said of excuses, so too-I now think — for significant apologies. In my discussion from now on, I will be concerned with apologies in a context of seriousness (serious wrong, serious harm) and will thus use the word "apology" in the way I take appropriate to such a context.

46 When we promise we invite people to count on us - sometimes in very significant ways-and this in part explains why promises typically create moral obligations. It is hard to see how promises could function in this way if they were not taken to be sincere expressions of intent. Apologies, with respect to serious matters, typically invite wronged parties to think better of the wrongdoer and perhaps even to forgive him and restore relations with him. It is hard to see how apologies could function in this way if they were not taken to be sincere expressions of remorse.

47 J. L. Austin, A Plea for Excuses, in Philosophical Papers 142-43 (1961). 
One of the reasons that apologies sometimes misfire is because the person supposedly apologizing fails to represent the right kind of sorrow-e.g., saying that he is sorry that you interpreted his (presumably innocent) remark in such a way that your (probably overly sensitive) feelings were hurt. This fails as an apology because, in mislocating the proper object for the sorrow, it fails to acknowledge the genuine wrongdoing that a genuine apology would address. (Although Stanley Williams expressed some general regrets with respect to his previous life of crime, he did not express regrets - much less apologize or express remorse-with respect to the crimes of which he had been, in the judgment of Governor Schwarzenegger, rightfully convicted. Thus even the expressed regrets, having the wrong target, were judged by the governor to be irrelevant to the clemency decision.)

As I write this essay, the news is filled with reports of another misfired apology - this time from actor Mel Gibson. It is not surprising that his first apology for the anti-Semitic tirade he delivered when being arrested for drunken driving was regarded by many to be insufficient since he merely expressed general regrets for having said things that (so he claimed) he does not really believe. Small wonder that Abraham H. Foxman of the Anti-Defamation League rejected this apology as "unremorseful and insufficient." that has become so common in America-Gibson (perhaps coached by his agent) making a second apology that actually mentions anti-Semitism and claims that he is not anti-Semitic, the Anti-Defamation League giving a reluctant and qualified partial acceptance of that apology, discussions of possible cooperative projects of healing, and so on it goes. ${ }^{49}$ The shelf life of this dance will surely expire in about another week and will probably have as its primary public value the production of some great comedy. Not since the person shot by Vice-President Dick Cheney in a hunting accident publicly apologized to Cheney for causing him and his family distress have Jay Leno, Jon Stewart, and Steven Colbert had something so choice to work with. (I still recall with pleasure a gem about the Cheney incident that came from Jon Stewart: "Just imagine how powerful you have to be if when you shoot somebody he apologizes to you.") Perhaps comedy is the way that some of us get "closure" from the suffocatingly boring and shallow apology dances to which we are now so often exposed.

Even when representations of remorse and repentance are directed to the proper object, however, it is important to remember that representations are simply representations. They are not the same as actual remorse and repentance. The convincing fraud who makes an insincere apology really has apologized in the Austinian sense, but in a context of seriousness we normally take an apology to be something more than an Austinian performative. We take it to represent sincere

48 Press Release, Anti-Defamation League, ADL Says Mel Gibson's Anti-Semitic Tirade Reveals His True Self; Actor's Apology 'Not Good Enough', at http://www.adl.org/PresRele/ASUS_12/4861 _12.htm (last visited Nov. 2, 2006).

E1.

49 Allison Hope Weiner, Mel Gibson Seeks Forgiveness From News, N.Y. TMES, Aug. 2, 2006, at 
remorse, and so we may reject the apology as an insulting piece of mere acting-one sense of "performance"-if we believe that there is in fact no remorse, that the representation is nothing but a representation.

Is apology in the absence of genuine sincerity enough so long as it represents sincerity? I think that it sometimes is and sometimes is not. It all depends on what one wants out of an apology. If one wants admission of and acceptance of responsibility, a properly constructed apology provides that - although, as the South African TRC reveals, one can also get that without apology. How? Simply by having the wrongdoer explicitly disclose facts that establish wrongdoing and accept responsibility for what he has done. An apology does that but, in also representing remorse, it does more than that.

There are also some retributive satisfactions that can be gained even fromperhaps especially from-an insincere public apology. To force someone to make a public apology is to subject that person to a social ritual that can be painfully humiliating for that person-particularly, I should think, if that person is not sincerely sorry. Some victims of wrongdoing might not care about the sincerity of the apology, however, so long as the making of the apology is painful to the right degree for the person who must deliver it. That it causes deserved suffering might be satisfaction enough for those who are retributively inclined. Thus the public disclosure of wrongdoing, required by the TRC as a condition for amnesty, may have had more retributive bite than Bishop Tutu-who likes to think of the TRC as "restorative justice" rather than "retributive justice"-likes to admit. For at least some people it must be quite painful, even if one does not apologize or express remorse, simply to acknowledge in public-including before one's friends and family and fellow parishioners - that, for example, one of the tasks performed as a government police officer was to torture and sometimes even kill suspects or prisoners. Mere humiliating public disclosure without apology can sometimes provide retributive satisfaction to victims-the reason why truth commissions (such as Chile's) that do not publish names of wrongdoers often seem less satisfying to victims than those (such as South Africa's) that do. But if mere disclosure without apology can provide retributive satisfaction to victims, it might be the case that requiring an apology as a condition of amnesty or clemency, even if that apology is insincere or suspected to be so, might provide even more retributive satisfactions to those victims.

Many, of course, might regard the retributive satisfactions afforded some victims by rituals of humiliation - particularly if those rituals require what may be insincere apologies and expressions of remorse - as bought at too high a moral and political price. This is perhaps why, in the Coetzee novel, David Lurie compared the demand that he make a public apology to the humiliating rituals of Mao's China during the Cultural Revolution.

I am personally conflicted about this matter. Sometimes I favor public humiliation as a punishment and have even suggested, for example, that a good punishment for a student or faculty plagiarist is to force that person to apologize in front of the entire academic community of which he is a member and to endure the 
shame that is his due. There are other times, however, when I share David Lurie's reservations and think that the self that desires the humiliation of others, even in a just cause, is not my better self.

Even if one can imagine a place for public apology as a shaming punishment in the academic world, however, it is not at all clear that one should welcome this in the realm of legal punishment. An academic community may be presumed, without 1 hope too much self-deceptive fiction, to be bound together by shared values-to be, in short, a genuine community. I fear that many of those who advocate a greater role for apology and expressions of remorse in American criminal law may overestimate the degree of actual community present in our large and complex society with its massive social class and racial and cultural divisions. Such advocates often speak warmly of the capacity of apology to lead to reconciliation and reintegration with the larger community - an idea that makes perfect sense where there is a genuine community but is ludicrous when applied to persons who are so alienated that they have never felt a part of the larger community in the first place. ${ }^{50}$ Apology advocates may also have too rosy a picture of the nature of the communitarian society that would make talk of deep reintegration and reconciliation through apology rituals genuinely possible. What was Mao's China, after all, except what might be called communitarianism on steroids?

\section{CONCLUSION}

It will surely come as no surprise that the skepticism I earlier expressed concerning the possible role of repentance and remorse as grounds for mercy (particularly in sentencing) I now extend to apology as well. A truly sincere apology can be a wonderful, even blessed, thing since it involves the kind of remorse and repentance that often marks a step on the road to moral rebirth, can sometimes provide legitimate comfort to victims, and in the proper sort of cases can indeed lead to a valuable kind of reconciliation. Turn all of that over to the American system of assembly line justice, however, a system starved for resources and staffed by people who are oppressively overworked and in a hurry to clear cases, and we will--I feardo little more than cheapen the currency of the real thing and add to the cynicism about our system of criminal law, and indeed about our society in general, that grows greater each passing day. Just recall the shameful spectacle of President Clinton in the Monica Lewinsky matter. So quick and frequent were his apologies that one could use his example to make a case that apologizing can now be added to the list of obsessive-compulsive disorders, and this not surprisingly made him the brunt of a variety of jokes and cynical comments. And recall the cynical New Yorker cartoon I quoted earlier and the new novel Eating Crow by Jay Rayner. Cynical jokes about public apology are already the order of the day, and I cannot see an expanded role for apology in criminal sentencing as doing anything more than adding to this cynical

so See Jeffrie G. Murphy, Marxism and Retribution, 2 PHIL. \& PuB. AfF. 217 (1973). 
perspective - a very funny one, indeed, but not in my view one that contributes to a healthy society. As the New Yorker cartoon suggests, apology in America may not even be shaming these days - in which case there go even the retributive satisfactions that might, as noted earlier, be gained by victims from an apology even if that apology is insincere and known to be so. Just as bankruptcy has generally ceased to be an occasion of shame and has become instead a business or personal planning tool, so might a willingness to apologize if necessary be little more than part of a rational strategy for maximizing one's self interest.

As with remorse, however, the role of apology strikes me as less controversial in clemency decisions than in sentencing decisions. My reason for this is the same as given with respect to remorse: less risk of mistakes because of the greater time and more extensive evidential base that clemency decisions make possible. Here the evidence gathered may not simply go to the sincerity of the person making the apology but also to the likely impact, for good or ill, that the apology will have on victims and on society as a whole.

I am an enemy neither of apology nor remorse; and indeed I have here acknowledged, at least in passing, that apologies (particularly when sincerely expressive of remorse) can sometimes have many virtues - both individual and social. In a different social and historical context I might have wanted more to stress those virtues and discuss them in more detail. Our present intellectual culture, however, strikes me as one in which apology and other expressions of remorse are often located (and often over praised) in the context of a sentimental ideology of therapy and healing rather than, say, an ideology of truth and justice.

As a counter to this sentimental ideology, I have been concerned here mainly to express some skepticism, both substantively and rhetorically, toward the trendy celebration of apology and expressions of remorse and to the uncritical extension of that celebration into criminal law. Mainly for evidential reasons, my skepticism is much greater when remorse and apology are offered as grounds for mercy in sentencing than when they are offered as grounds for mercy in clemency decisions. However, as Governor Schwarzenegger's thoughtful denial of clemency to Stanley Williams suggests (at least to those who do not regard Williams to have been innocent of the murders of which he was convicted), a healthy dose of skepticism is well in order in the domain of clemency as well.

I would not, however, want my qualified sympathy with Governor Schwarzenegger's clemency decision in the narrow confines of that one case to be taken as a sign that I am at all comfortable with the general context in which such decisions must be made. So, as a final point, let me baldly state my view that the whole American system of so-called "criminal justice" has to a great degree become a moral and administrative mess - a great bloated monster driven by competing and sometimes inconsistent values, and sometimes by no values at all but simply by cruelty or indifference or institutional inertia. It calls, in my judgment, for radical rethinking and redesign. Thus I cannot help thinking that spending a lot of time tinkering with the small corners of the present system that might be affected by 
remorse and apology is rather like, as the saying goes, rearranging the furniture on the decks of the Titanic. That, however, is a topic for another occasion. 
